
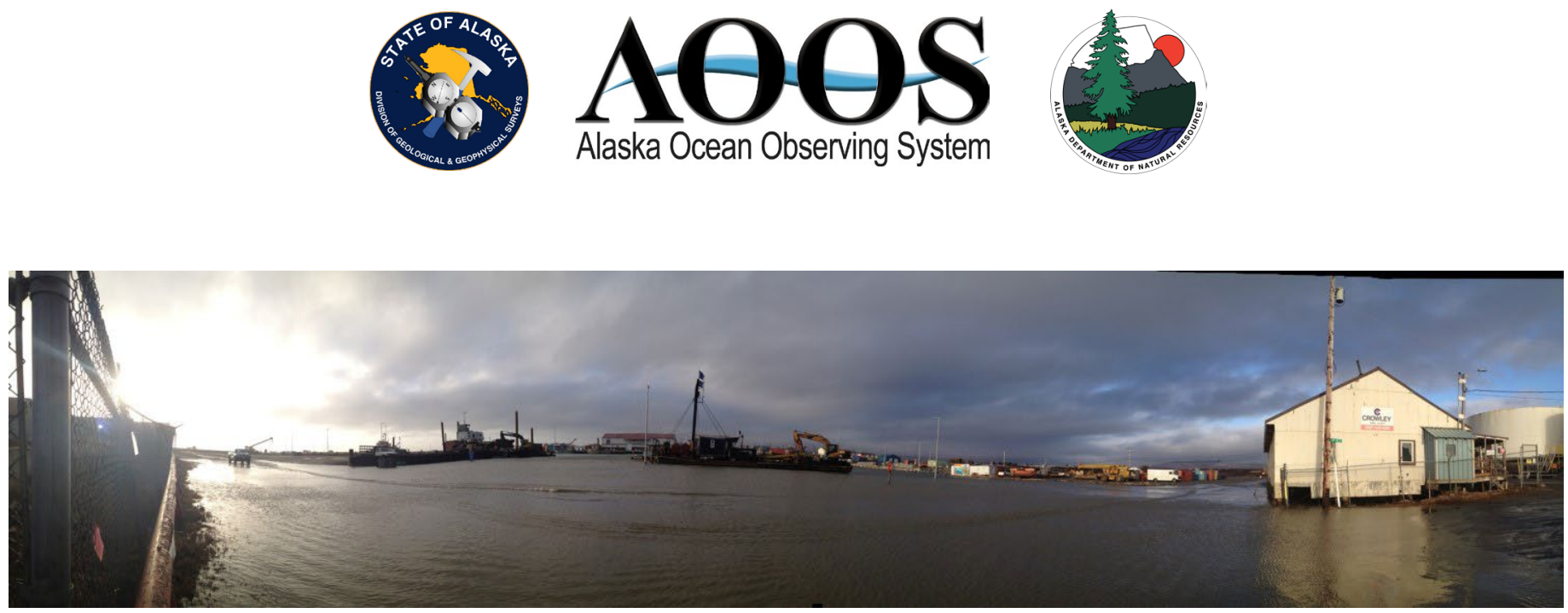

STORM WATER LEVEL FEATURE EXTRACTION FROM DIGITAL ELEVATION MODELS USING INTRA-STORM PHOTOGRAPHS

Jacquelyn R. Overbeck 

STORM WATER LEVEL FEATURE EXTRACTION FROM DIGITAL ELEVATION MODELS USING INTRA-STORM PHOTOGRAPHS

Jacquelyn R. Overbeck

Report of Investigations 2017-6

State of Alaska

Department of Natural Resources

Division of Geological \& Geophysical Surveys 



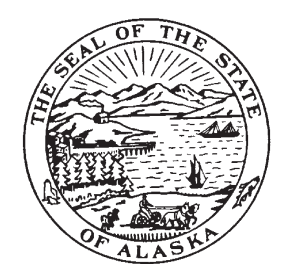

STATE OF ALASKA

Bill Walker, Governor

\section{DEPARTMENT OF NATURAL RESOURCES}

Andrew T. Mack, Commissioner

\section{DIVISION OF GEOLOGICAL \& GEOPHYSICAL SURVEYS}

Steve Masterman, State Geologist and Director

Publications produced by the Division of Geological \& Geophysical Surveys (DGGS) are available for download from the DGGS website (dggs.alaska.gov). Publications on hard-copy or digital media can be examined or purchased in the Fairbanks office:

\section{Alaska Division of Geological \& Geophysical Surveys 3354 College Rd., Fairbanks, Alaska 99709-3707 \\ Phone: (907) 451-5010 Fax (907) 451-5050 \\ dggspubs@alaska.gov \\ dggs.alaska.gov}

\author{
Alaska State Library \\ Historical Collections \& \\ Talking Book Center \\ 395 Whittier Street \\ Juneau, Alaska 99811
}

\author{
Alaska Resource Library \& \\ Information Services (ARLIS) \\ 3150 C Street, Suite 100 \\ Anchorage, Alaska 99503-3982
}





\section{CONTENTS}

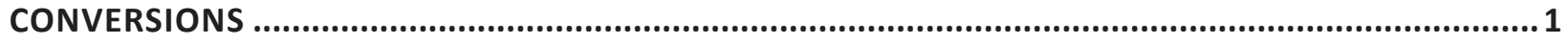

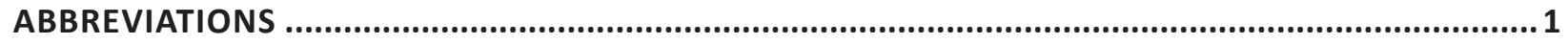

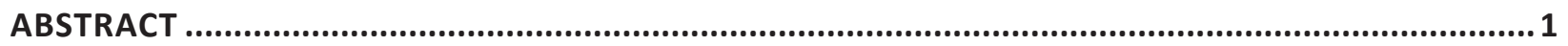

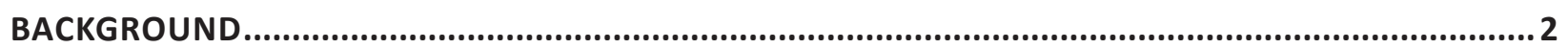

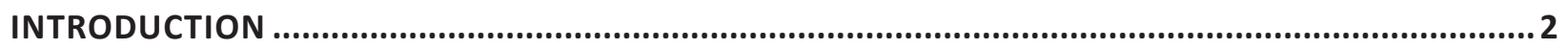

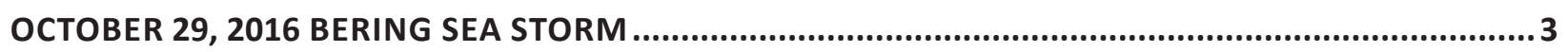

DATA

High Resolution Digital Elevation Models (DEMs) and Orthoimagery............................................ 5

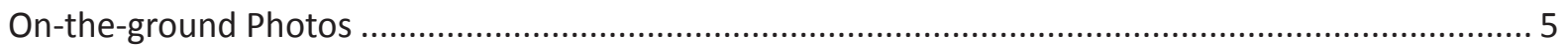

Measured SWL

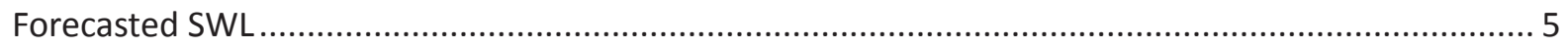

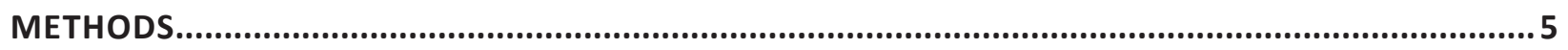

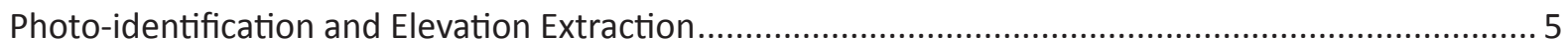

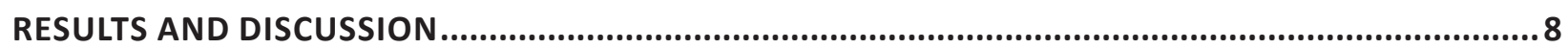

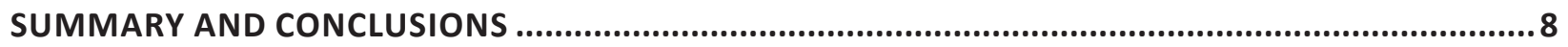

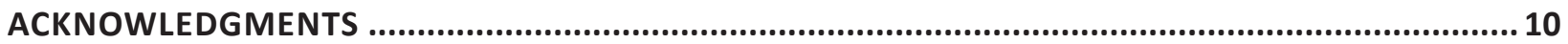

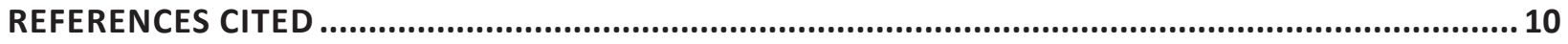

\section{FIGURES}

Figure 1. Water level components that contribute to storm water levels on exposed coasts and

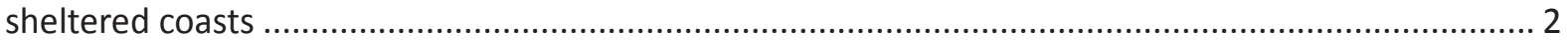

Figure 2. Measured water level, barometric pressure, and wind speed, and predicted astronomical tides at the NOAA tide gage at Nome; with wind rose and location map.......................................... 4

Figure 3. Photographs at Golovin taken at the peak of the storm, locations identified on the orthoimagery, and the locations where points were extracted from the digital elevation model......... 6

Figure 4. Photographs taken at Nome at the peak of the storm, locations identified on the orthoimagery, and the locations where points were extracted from the digital elevation model......... 7

Figure 5. Extracted elevations of approximate water levels at Golovin for sheltered coast

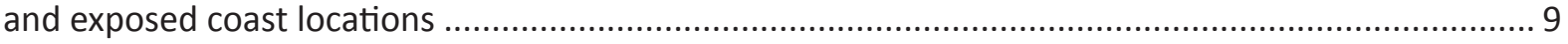

Figure 6. Extracted elevations of approximate water levels at Nome for sheltered coast and

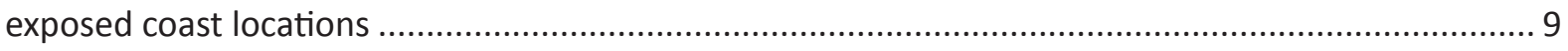

\section{TABLES}

Table 1. Water level components ................................................................................................ 3

Table 2. Parameters for DEMs and Orthoimages............................................................................ 5

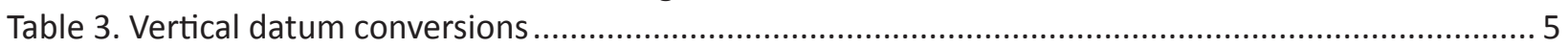

Table 4. Water level comparison between forecasted and measured SWL and photo-measured SWL

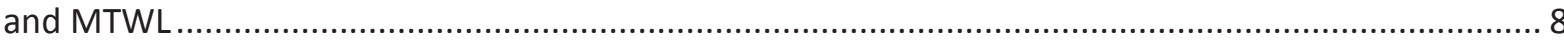





\title{
STORM WATER LEVEL FEATURE EXTRACTION FROM DIGITAL ELEVATION MODELS USING INTRA-STORM PHOTOGRAPHS
}

\author{
Jacquelyn R. Overbeck ${ }^{1}$
}

\section{Conversions}

1 meter $=3.281$ feet

1 knot $=1.151$ miles per hour (0.514 meters/second)

$\quad$ Abbreviations
AKST = Alaska Standard Time
DEM = Digital Elevation Model
DSM = Digital Surface Model
ETSS = Extratropical Storm Surge
GPS = Global Positioning System
GSD = Ground Sample Distance
$\mathrm{ft}=$ feet
$\mathrm{kn}=$ knots
$\mathrm{m}=$ meters
MSL = Mean Sea Level = Average hourly water level as calculated over a tidal epoch
NAVD88 = North American Vertical Datum of 1988
NOAA = National Oceanic and Atmospheric Administration
MTWL = Marine Total Water Level; elevation of water level in coastal setting which includes tides,
$\quad$ non-tidal residuals, and wave-induced components
Orthoimagery = Orthorectified aerial imagery
RMSE = Root Mean Square Error
SWL = Still Water Level

\begin{abstract}
Alaska is subject to extratropical cyclones that move across the Bering Sea and result in flooding and erosion on its western coast. The local water level elevations on the coast resulting from storms are necessary data to validate storm forecasts and hindcast models that are used to warn local residents. Water level data is sparse along the Alaska coast, due to large gaps in the national water level network and minimal oceanographic monitoring infrastructure. By improving the ability of local residents to collect water level data, new observations will contribute to improving storm forecasts, quantifying storm-impact, and evaluating changes to storm intensities and patterns. The recent release (2015-2016) of digital elevation models and orthorectified aerial imagery over a large portion of western Alaska make photo-to-elevation-based measurements of storm water levels possible. Local residents collected on-theground photographs at Nome and Golovin during the peak of a storm on October 29, 2016. Photographs were collected on exposed and sheltered coasts. Inundation extents were delineated relative to the locations of buildings, vegetation features, and rock revetments on orthorectified aerial photography. Elevations were extracted using the delineated areas from co-registered digital elevation models to determine storm water level elevations. Storm water level elevations were compared to measured and forecasted water levels to determine the difference to photo-derived water levels. Photo-derived water levels on sheltered coasts were slightly higher, suggesting terrestrial inputs may have enhanced water levels. Photo-derived water levels at exposed coast locations-where wave-induced water levels were expected to increase the photo-derived measurement-have the highest difference. Photo-derived water levels collected on a rock revetment-representing a steep and uneven ground surface-had the largest compared difference and greatest standard deviation, making the ground surface unsuitable for this method of water level extraction. Study results show that the extraction of water level elevations from photo-documented inundation extents on low-slope, even ground surfaces is a valid method for determining maximum water levels where oceanographic monitoring equipment are not operational and where high resolution orthoimagery and digital elevation models are available.
\end{abstract}

${ }^{1}$ Alaska Division of Geological \& Geophysical Surveys, 3651 Penland Pkwy Anchorage, AK, 99508; jacquelyn.overbeck@alaska.gov. 


\section{BACKGROUND}

Extratropical cyclones originating in the Bering Sea come in contact with waters of the shallow continental shelf bordering Alaska, resulting in setup of wind-driven waves and barometric pressure-driven surge (Blier and others, 1997). Storms regularly occur in the fall and winter with varying levels of flooding and erosion that largely depend on sea-ice cover in the offshore and nearshore environment (Wise and others, 1981). Communities on the west coast of Alaska are subject to flooding and erosion, and, although many reports describe them as imminently threatened (GAO, 2003; GAO, 2009; USACE, 2009), quantitative data about the magnitude of potential storm water levels are still needed to make informed mitigation or community planning goals to address local risks. Quantitative data, including maximum water level elevations due to wave runup, storm surge, and tide, are also necessary for mapping, improving storm forecasts, and validating models for long-term predictions of flooding and erosion. Measuring the maximum elevation of water levels remains a difficult task in Alaska because of the paucity of oceanographic monitoring equipment in the nearshore coastal zone. Barriers to installing and maintaining oceanographic equipment include remoteness of monitoring sites, extreme weather and temperature conditions, and limited internet access for data transfer (AOOS, 2016). The research described here introduces a method for documenting coastal water elevations from storms where minimal oceanographic equipment are in operation.

\section{INTRODUCTION}

Inundation on the coast is the sum of water-level components including astronomical tides, non-tidal residuals, and wave-induced water levels that together add up to marine total water level (MTWL; Moritz and others, 2016). Inundation can vary spatially and temporally and is affected by local beach morphology as well as the coastal setting (e.g. open coast, estuary, rocky or sandy beach; fig. 1). For coastlines exposed to waves, wave-induced water level components include wave setup and setdown, wave groups (surf beat), and wave runup and swash (incident and infragravity). For sheltered coasts such as estuaries, non-tidal residuals include terrestrial inputs including precipitation, river discharge, groundwater, and interior ponding. Both settings are also influenced by non-tidal residuals that include seasonal cycles, monthly mean sea-level anomalies, and storm surge (Moritz and others, 2016). Each water level component requires advanced monitoring equipment to parse out individual signals. For this research, water level components have been simplified and defined for comparison (table 1).

Observations of water levels at the coastline are made using a variety of monitoring equipment (GPS buoy, staff, float, bubbler, direct pressure transducer, acoustic, microwave, radio, satellite, sonar, and laser; AOOS,

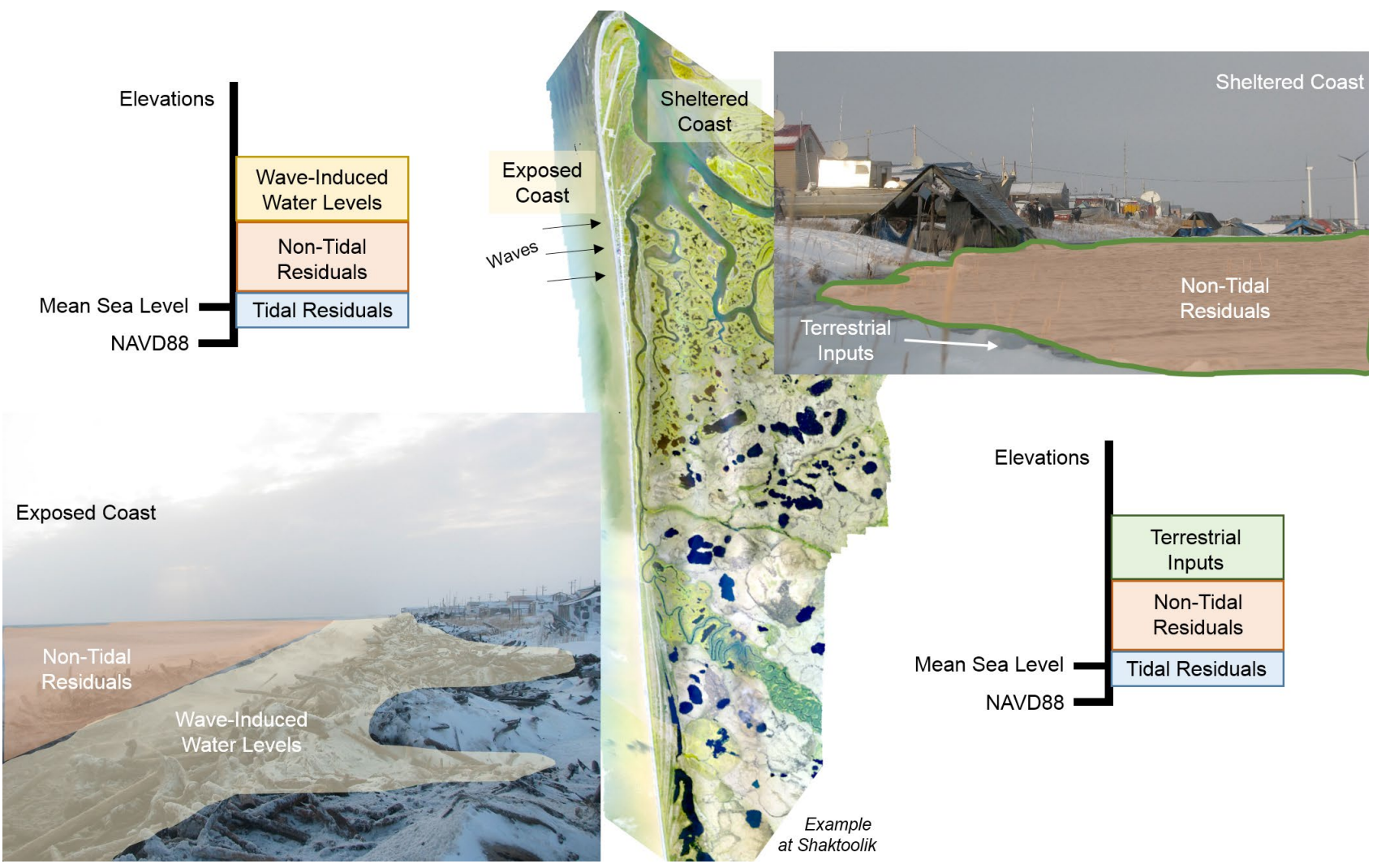

Figure 1. Water level components that contribute to storm water levels on exposed coasts (left) and sheltered coasts (right). Photos taken at Shaktoolik, November 2011. 
2016). Components of MTWL can be extracted from these observations, however, different monitoring devices measure different MTWL components. Many MTWL components (ex. wave runup, setup, or swash) also require long-term or high-frequency (frequently repeated) records of observations in order to effectively determine the magnitude of that component. In Alaska, where there is minimal observational equipment, equipment have been operating for short periods of time, and/or collect at low frequencies, most equipment only measure still water level (SWL) on exposed or sheltered coasts. The National Oceanic and Atmospheric Administration (NOAA) tide gauge at Nome used in this study (9468756; NOAA, 2016b) measures SWL on the exposed coast.

Models of storm-induced water levels separately take into account individual water level components. The Alaska Extratropical Storm Surge (ETSS) model operated by the NOAA National Weather Service (NWS) accounts for SWL components without terrestrial inputs (similar to the NOAA tide gauge; NOAA, 2016a). The ETSS model is currently the only operational model for forecasting floods in Alaska. Other models that include wave-induced components do exist but are not currently operational in Alaska (e.g. XBeach, SBeach, parameterized models, etc.).

Photographs of inundation, such as the ones collected for this research, can be taken on either the exposed or sheltered coast. Photos of the exposed coast depict the MTWL at the time the photo was taken, which includes SWL and wave-induced components, but not necessarily the maximum wave-induced component. A photograph taken of the sheltered coast represents SWL influenced by terrestrial inputs; however, maximum surge and maximum terrestrial inputs may be temporally offset from each other and minimal terrestrial inputs are expected during freezing temperatures.

\section{OCTOBER 29, 2016 BERING SEA STORM}

During the week of October 23, 2016, multiple low pressure weather systems were forecasted by NWS to pass through the Bering Strait off the coast of Alaska. At 3:06 pm (AKST) on October 29, the peak of SWL for the second low pressure system passed through Nome (fig. 2). Maximum sustained winds were out of the southeast at 37.7 knots $(19.4 \mathrm{~m} / \mathrm{s})$ with gusts up to 45.1 knots $(23.2$ $\mathrm{m} / \mathrm{s}$; NOAA, 2016b). Minor flooding was reported at individual communities along the coast, including near the Nome tide gauge, and at locations with no monitoring equipment (Golovin). Local residents took photographs at each community at maximum flood levels. Photoidentified locations were then used to delineate an area of assumed inundation on orthorectified aerial photographs and elevations were extracted from a co-registered digital surface model. By using the photographs in combination with elevation data, observations of SWL and MTWL were made at sheltered and exposed locations independent of tidal gauges. The measurement of SWL from the Nome tide gauge was used to assess the accuracy of the extracted water level elevations.

Table 1. Water level components (Moritz and others, 2016), colors coordinate with figure 1.

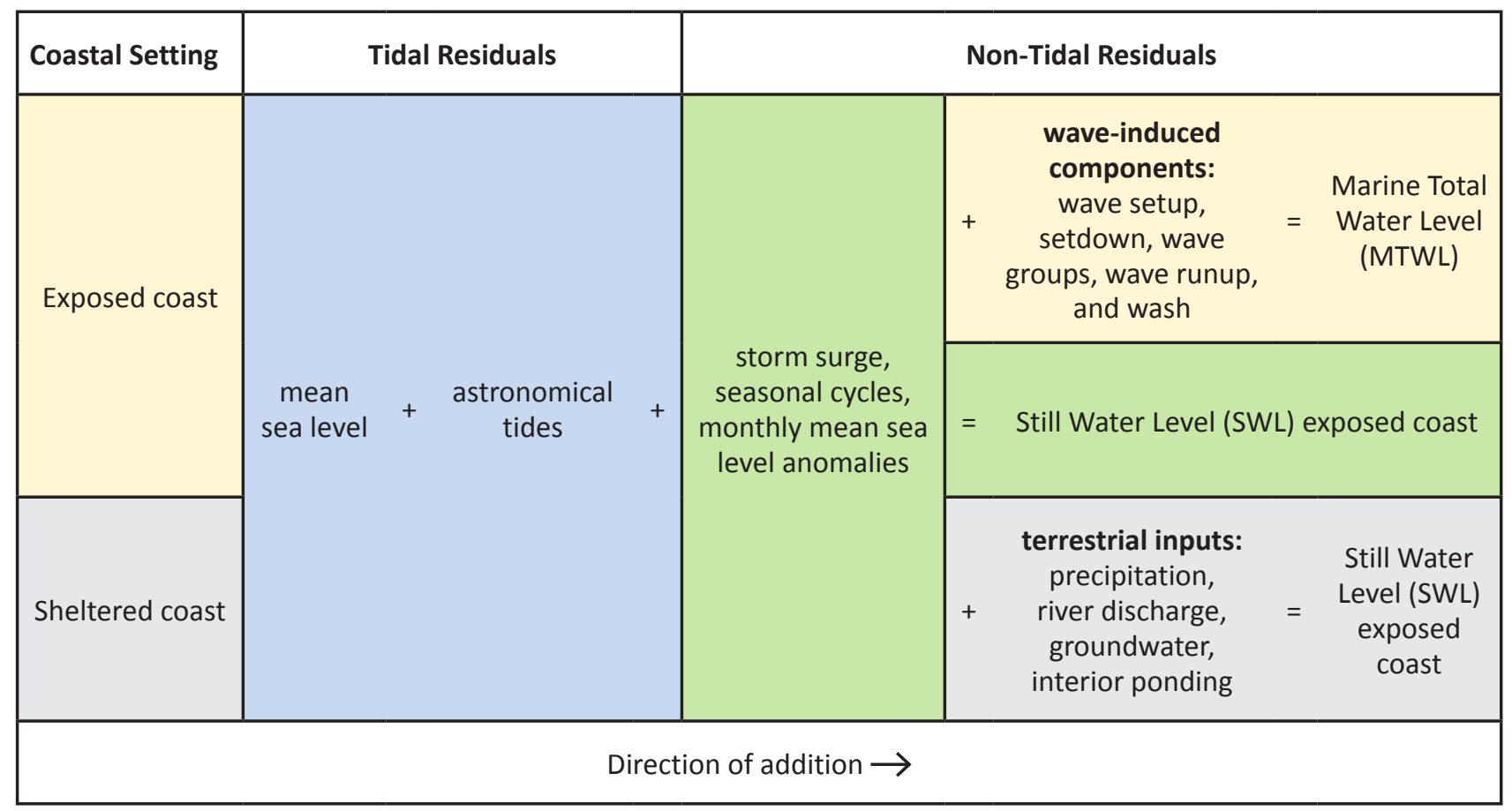


a.
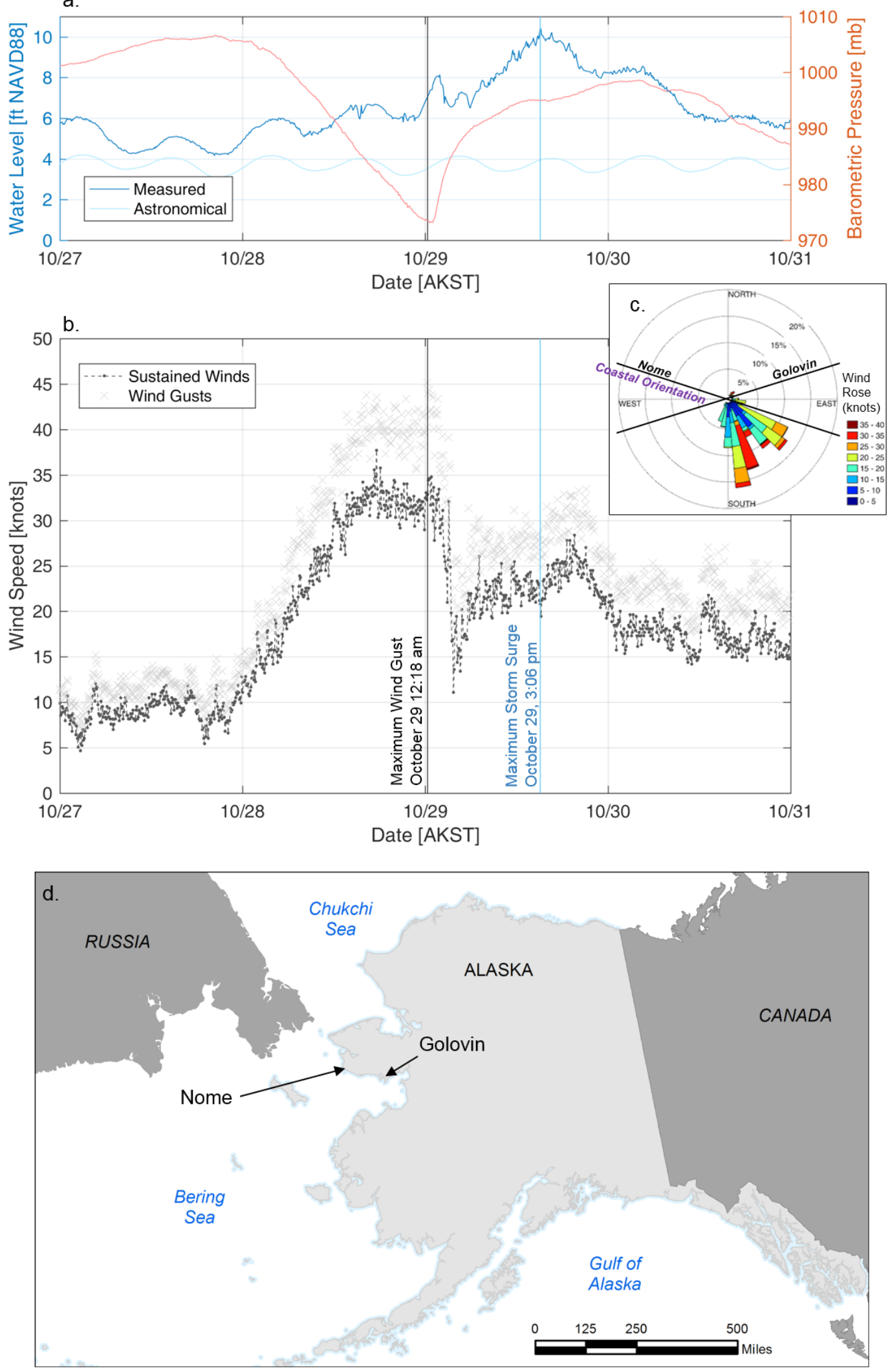

Figure 2. (a) Measured water level, predicted astronomical tides, and barometric pressure, and (b) sustained and gusting wind speeds from 10/27 to 10/31, 2016 (AKST) measured at the NOAA tide gauge in Nome. (c) Wind rose represents binned wind speeds at the Nome tide gauge. (d) Overview map showing community locations. 
DATA

\section{HIGH RESOLUTION DIGITAL ELEVATION MODELS (DEMS) AND ORTHOIMAGERY}

Elevation data and orthoimagery were generated from aerial photographs collected over western Alaska in 2015. The photographs were processed using Structure-fromMotion (SfM) photogrammetry and vertically shifted to control ground elevations (relative to NAVD88) to achieve centimeter-level vertical root-mean-square error (RMSE; table 2; Overbeck and others, 2016). Horizontal accuracy of the orthoimagery was sub-pixel (below the ground sample distance of the data; GSD; Overbeck and others, 2016). The sub-meter GSD makes houses and linear features near houses identifiable in the orthoimagery.

\section{ON-THE-GROUND PHOTOS}

Residents of western Alaska communities were contacted by the Alaska Division of Geological \& Geophysical Surveys (DGGS) before the October 29, 2016 (AKST), storm and asked to take photographs and GPS points of the maximum flooding extents. Residents from Nome and Golovin provided photos from personal cameras of multiple identifiable locations around each community during maximum flooding. Although GPS locations were not collected with the photographs, approximate locations of maximum flooding were visible in both the photos and the orthoimagery. Photos were collected at both exposed and sheltered coasts at Nome and Golovin.
MEASURED SWL

NOAA tide gauge 9468756 (Nome) was the only operational water level gauge with accompanying photographs during the storm. The maximum SWL elevation measured at Nome was $6.83 \mathrm{ft}$ above MSL (NOAA, 2016b; table 3; fig. 2). Water level elevations were converted to a land-based datum (NAVD88) to directly compare to photographed water level elevations extracted from DEMs at Nome (table 3).

\section{FORECASTED SWL}

The National Weather Service forecast for the southern Seward Peninsula coast including Nome, White Mountain, and Golovin at 3:41 am on Friday, October 28,2016 , was for a high surf advisory, with storm surge as high as 5 to $6 \mathrm{ft}$ above MSL (personal communication with Edward Plumb, Fairbanks Weather Service Forecast Office, NOAA; table 3). Storm surge predictions were based on the Alaska ETSS model (NOAA, 2016a). The forecasted water level elevations were also converted to NAVD88 and compared to photographed water level elevations extracted from DEMs at Golovin (table 3).

\section{METHODS}

\section{PHOTO-IDENTIFICATION AND ELEVATION EXTRACTION}

Photographs collected by local residents were used to identify specific locations within both Golovin (fig. 3) and Nome (fig. 4) that either were flooded or where wave runup reached its maximum. Photos at Golovin

Table 2. Parameters for DEMs and Orthoimages (from Overbeck and others, 2016).

\begin{tabular}{|c|c|c|c|c|}
\hline Location & $\begin{array}{c}\text { Vertical RMSE } \\
(\mathbf{c m})\end{array}$ & $\begin{array}{c}\text { Number of } \\
\text { Ground } \\
\text { Control Points }\end{array}$ & $\begin{array}{c}\text { Orthoimagery } \\
\text { GSD }(\mathbf{c m})\end{array}$ & DSM GSD (cm) \\
\hline Nome & 9 & 5 & 9 & 18 \\
\hline Golovin & 3 & 4 & 10 & 20 \\
\hline
\end{tabular}

Table 3. Vertical datum conversions.

\begin{tabular}{|c|c|c|c|c|c|c|c|}
\hline & $\begin{array}{c}\text { SWL } \\
\text { (MSL ft) }\end{array}$ & $\begin{array}{c}\text { SWL } \\
\text { (MSL m) }\end{array}$ & $\begin{array}{c}\text { MSL } \\
\text { (ft NAVD88) }\end{array}$ & $\begin{array}{c}\text { MSL } \\
\text { (m NAVD88) }\end{array}$ & $\begin{array}{c}\text { SWL } \\
\text { (NAVD88 ft) }\end{array}$ & $\begin{array}{c}\text { SWL } \\
\text { (NAVD88 m) }\end{array}$ & $\begin{array}{c}\text { Conversion } \\
\text { Source }\end{array}$ \\
\hline $\begin{array}{c}\text { Nome } \\
\text { (Measured) }\end{array}$ & $6.83 \mathrm{ft}$ & $2.08 \mathrm{~m}$ & $3.45 \mathrm{ft}$ & $1.05 \mathrm{~m}$ & $10.36 \mathrm{ft}$ & $3.16 \mathrm{~m}$ & $\begin{array}{c}\text { (DGGS } \\
\text { Staff, 2017) }\end{array}$ \\
\hline $\begin{array}{c}\text { Golovin } \\
\text { (Forecasted) }\end{array}$ & $5-6 \mathrm{ft}$ & $1.52-1.83 \mathrm{~m}$ & $4.20 \mathrm{ft}$ & $1.28 \mathrm{~m}$ & $9.2-10.2 \mathrm{ft}$ & $\begin{array}{c}\text { 2.8-3.11 m } \\
\text { (Ond others, } \\
\text { 2015) }\end{array}$ \\
\hline
\end{tabular}



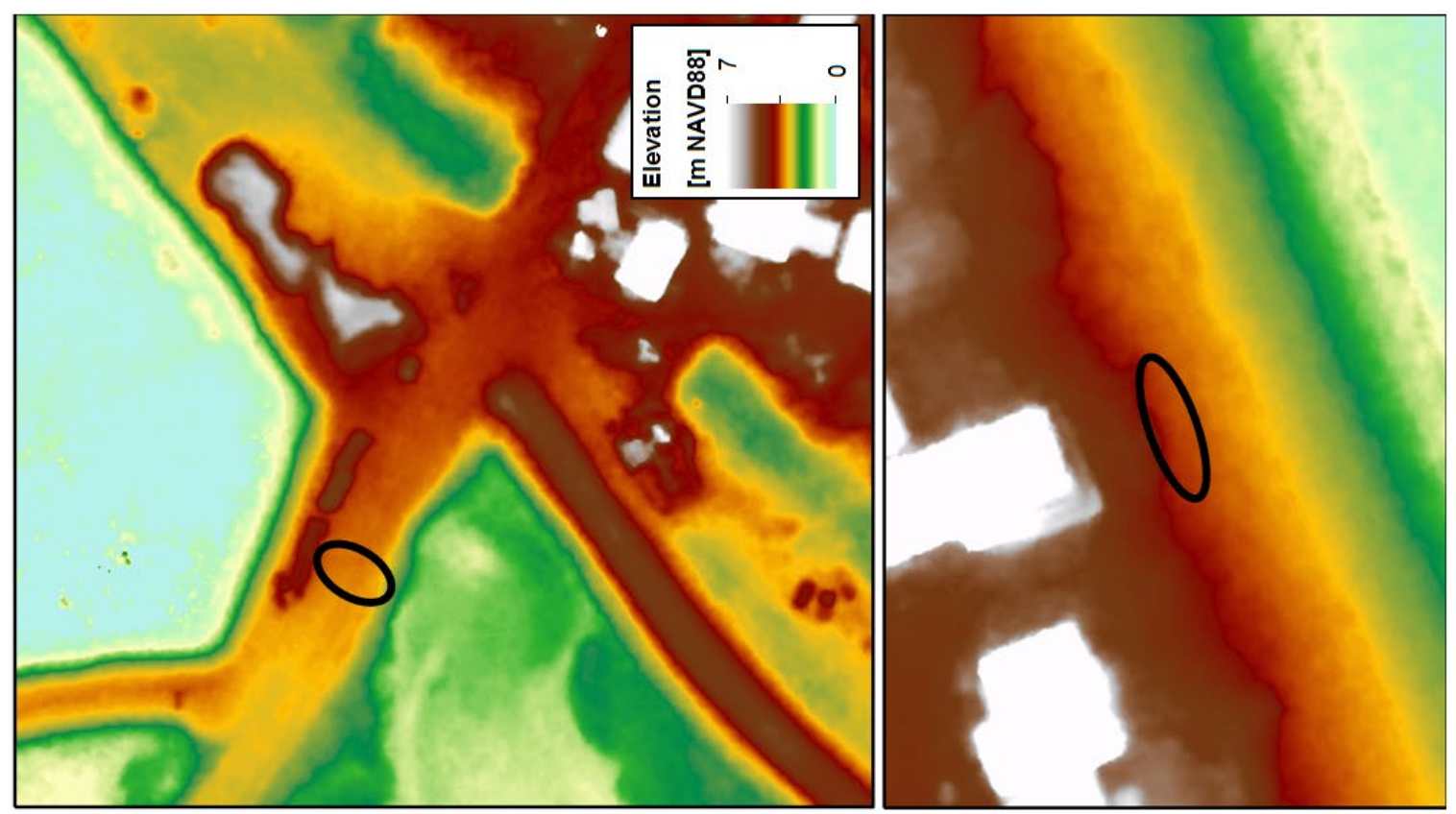

政
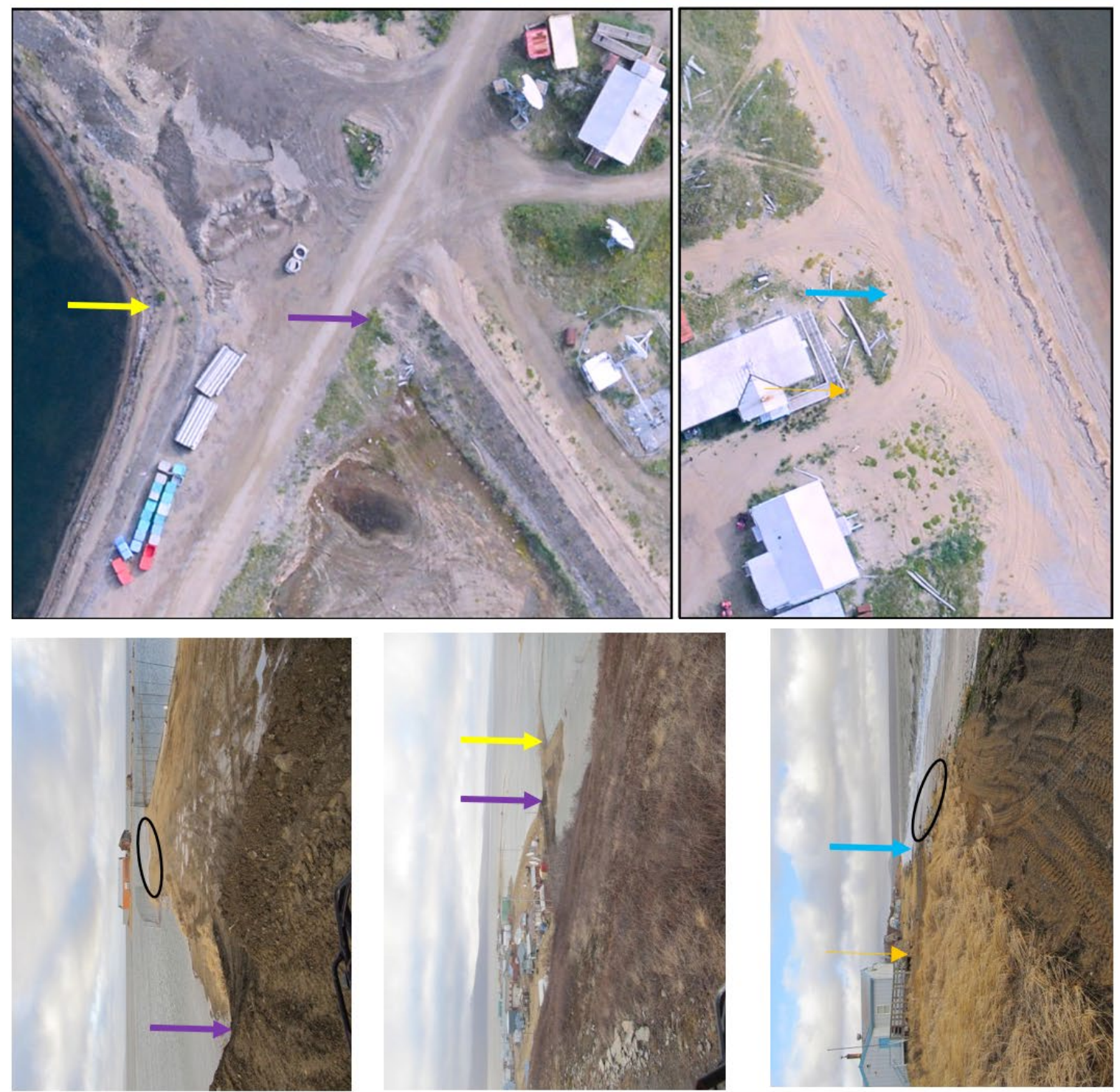

łsеоว рәرә||әપડ

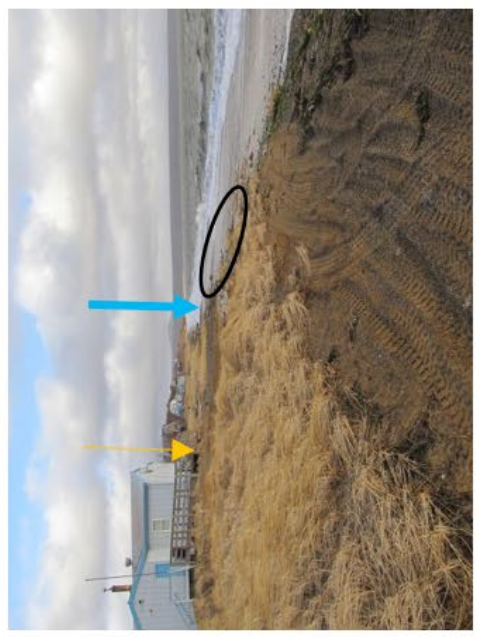

ıseoว pəsodx $\exists$

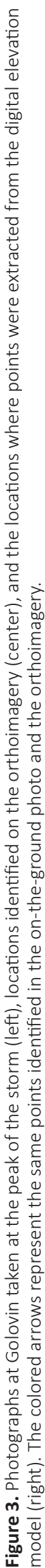




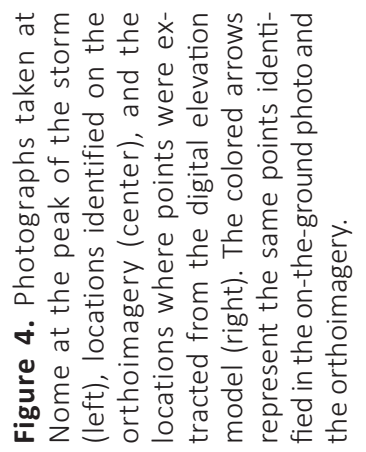
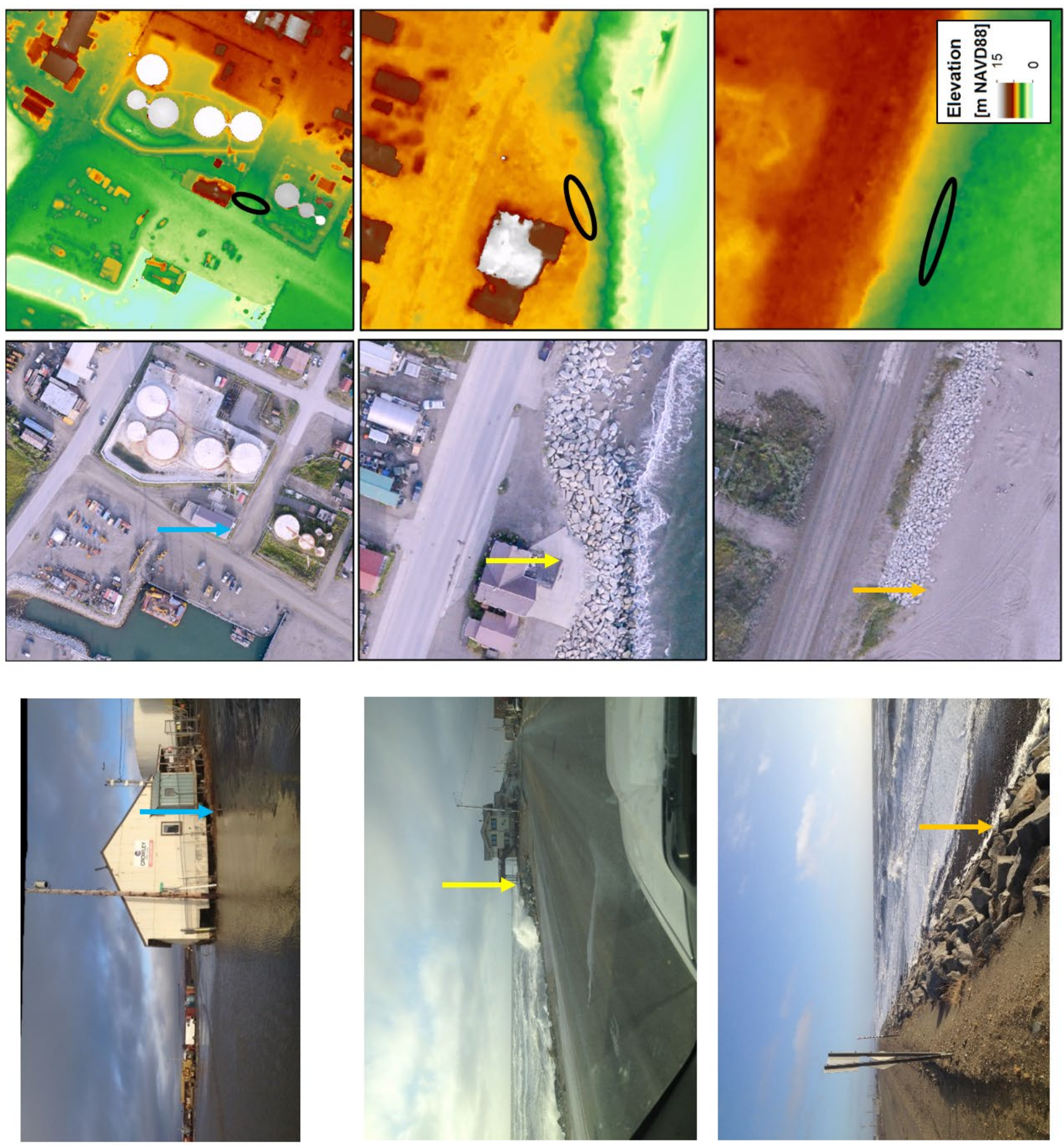

łseoว рәдәң|әчS

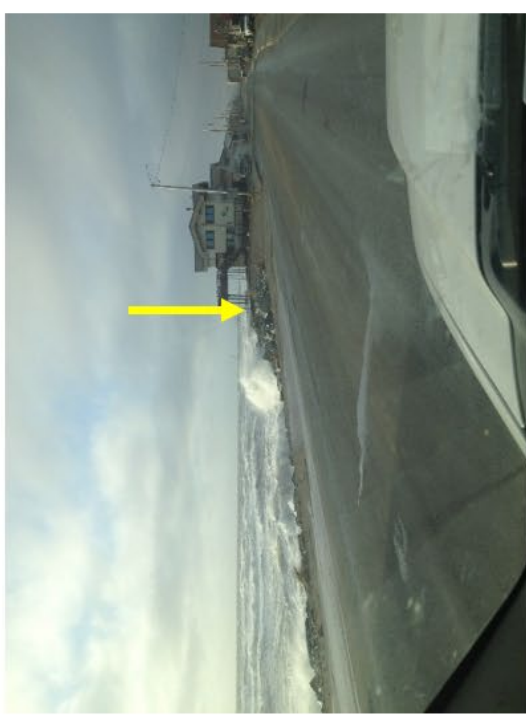

јиәшіәләу үәоу

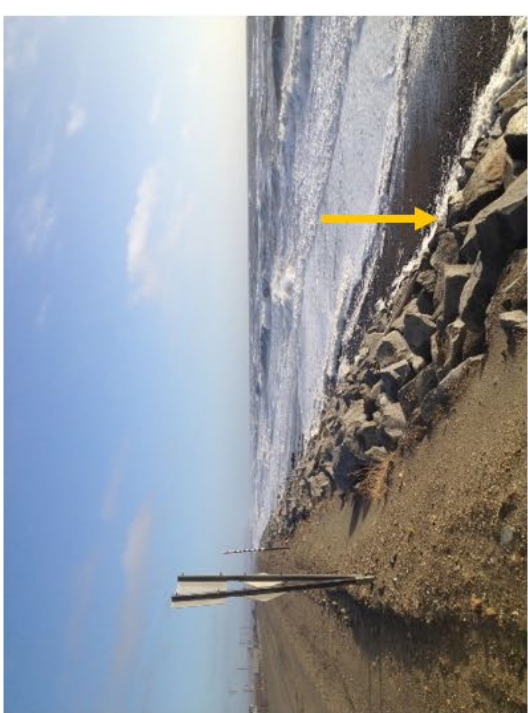

чәеәg pues 
were taken near the intersections of visible features such as a fence, a levee, and near the vegetation line fronting a house, which were identified on the orthoimagery. Photos at Nome were taken near a rock revetment and storefront. An area representing the photo-identified flood line was subjectively delineated on orthoimagery. Elevations were then extracted from the co-registered DEM. Extracted elevations at Nome were subtracted from the measured SWL elevation to determine the accuracy of this method. Extracted elevations at Golovin were subtracted from the forecasted SWL to show the applicability of this method to a location without oceanographic monitoring equipment. Standard deviations were computed from subtracted values to show the spread of the data over different ground surfaces and to provide better instruction for future efforts to photograph storm water levels.

\section{RESULTS AND DISCUSSION}

The photo-derived SWL elevation was slightly higher than measured SWL at Nome, although minimal (table 4). Photo-derived water level elevations were much higher on the exposed coast as compared to the sheltered coast. One scenario-located on a rock revetment-had the highest difference and greatest spread (standard deviation) between measured and photo-derived water levels. The difference between photo-derived SWL and forecasted SWL was also minimal at Golovin, so that if model predictions were correct, the photo-derived elevation was a good measure of SWL. For both Golovin and Nome, the spread of extracted water level elevations were smaller at lower-slope areas (fig. 5 and fig. 6; table 4).

For exposed coastlines, the difference in photo-derived and forecasted or measured water levels may be due to the difference in water level components measured. The on-the-ground photos take into account wave-induced water level components, resulting in MTWL, whereas the measured and forecasted values only represent SWL on the exposed coastline. Photos collected on the sheltered coastline had smaller differences than exposed coast locations when compared to the measured and forecasted values, which is likely because of the minimal effects of terrestrial inputs, making the sheltered and exposed SWLs more similar. The uneven and steep ground surface of the rock revetment likely resulted in the highest difference between compared water levels. Areas with lower slopes have more consistent elevations in general, making them a better location to pick out a large region of points and maintain a small spread of extracted elevations.

Based on the results of this analysis, suggestions for future photo-collections of storm water levels would include taking photos at or on:

1. the intersection of aerial photoidentifiable features,

2. low-slope ground surfaces,

3. even surfaces, and

4. multiple exposed and sheltered coastal locations.

The spread of elevations extracted from DEMs may also be reduced if photos are collected with GPS points, making the interpretation between visible features and the inundation extent more straightforward.

\section{SUMMARY AND CONCLUSIONS}

Photographs collected by local residents were used to extract storm water level elevations from digital surface models by identifying the inundation extent from on-the-

Table 4. Water level comparison between forecasted and measured SWL and photo-measured SWL and MTWL.

\begin{tabular}{|c|c|c|c|c|c|c|c|c|c|}
\hline Community & $\begin{array}{l}\text { Coastal } \\
\text { Setting }\end{array}$ & $\begin{array}{l}\text { Water Level } \\
\text { Components }\end{array}$ & $\begin{array}{l}\text { Ground } \\
\text { Material }\end{array}$ & $\begin{array}{l}\text { Steepness } \\
\text { (low/ } \\
\text { high) }\end{array}$ & $\begin{array}{l}\text { Forecasted/ } \\
\text { Measured } \\
\text { (NAVD88) }\end{array}$ & $\begin{array}{c}\text { Photo- } \\
\text { Derived } \\
\text { Water Levels }\end{array}$ & Difference & $\begin{array}{l}\text { Standard } \\
\text { Deviation }\end{array}$ & $\begin{array}{l}\text { Number (N) } \\
\text { of Elevations } \\
\text { Extracted } \\
\text { from DEM } \\
\text { for Analysis }\end{array}$ \\
\hline Golovin & Sheltered & SWL & Sandy & Low & \multirow{2}{*}{$\begin{array}{c}\text { Forecasted SWL } \\
\text { for Exposed } \\
\text { Coast } \\
9.2-10.2 \mathrm{ft} \\
(2.8-3.11 \mathrm{~m})\end{array}$} & $\begin{array}{c}10.9 \mathrm{ft} \\
(3.32 \mathrm{~m})\end{array}$ & $\begin{array}{c}0.7-1.7 \mathrm{ft} \\
(0.21-0.52 \mathrm{~m})\end{array}$ & $\begin{array}{c}0.13 \mathrm{ft} \\
(0.04 \mathrm{~m})\end{array}$ & 2942 \\
\hline Golovin & Exposed & MTWL & Sandy & Low & & $\begin{array}{c}11.8 \mathrm{ft} \\
(3.58 \mathrm{~m})\end{array}$ & $\begin{array}{c}1.6-2.6 \mathrm{ft} \\
(0.49-0.79 \mathrm{~m})\end{array}$ & $\begin{array}{c}0.26 \mathrm{ft} \\
(0.08 \mathrm{~m})\end{array}$ & 4824 \\
\hline Nome & Sheltered & SWL & $\begin{array}{l}\text { Pave- } \\
\text { ment }\end{array}$ & Low & \multirow{3}{*}{$\begin{array}{l}\text { Measured SWL } \\
\text { for Exposed } \\
\quad \text { Coast } \\
10.36 \mathrm{ft}(3.16 \mathrm{~m})\end{array}$} & $\begin{array}{l}11.16 \mathrm{ft} \\
(3.4 \mathrm{~m})\end{array}$ & $\begin{array}{c}0.8 \mathrm{ft} \\
(0.24 \mathrm{~m})\end{array}$ & $\begin{array}{c}0.26 \mathrm{ft} \\
(0.08 \mathrm{~m})\end{array}$ & 578 \\
\hline Nome & Exposed & MTWL & $\begin{array}{c}\text { Rock } \\
\text { Revet- } \\
\text { ment }\end{array}$ & High & & $\begin{array}{l}16.01 \mathrm{ft} \\
(4.88 \mathrm{~m})\end{array}$ & $\begin{array}{c}5.65 \mathrm{ft} \\
(1.72 \mathrm{~m})\end{array}$ & $\begin{array}{c}2.49 \mathrm{ft} \\
(0.76 \mathrm{~m})\end{array}$ & 849 \\
\hline Nome & Exposed & MTWL & Sandy & Low & & $\begin{array}{l}15.58 \mathrm{ft} \\
(4.75 \mathrm{~m})\end{array}$ & $\begin{array}{c}5.22 \mathrm{ft} \\
(1.59 \mathrm{~m})\end{array}$ & $\begin{array}{c}0.39 \mathrm{ft} \\
(0.12 \mathrm{~m})\end{array}$ & 508 \\
\hline
\end{tabular}



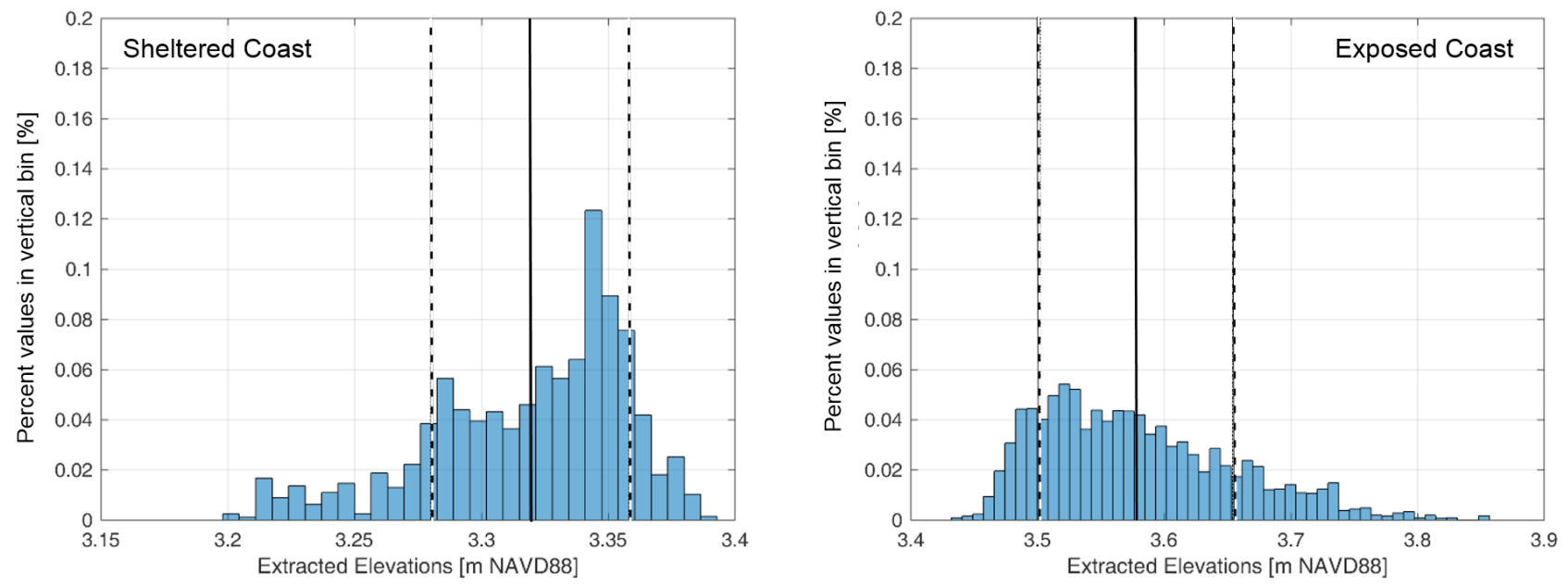

Figure 5. Extracted elevations of approximate water levels at Golovin for sheltered coast (left) and exposed coast (right) locations. Mean elevation is plotted as the solid black line +/-standard deviation at the dashed black and white lines.

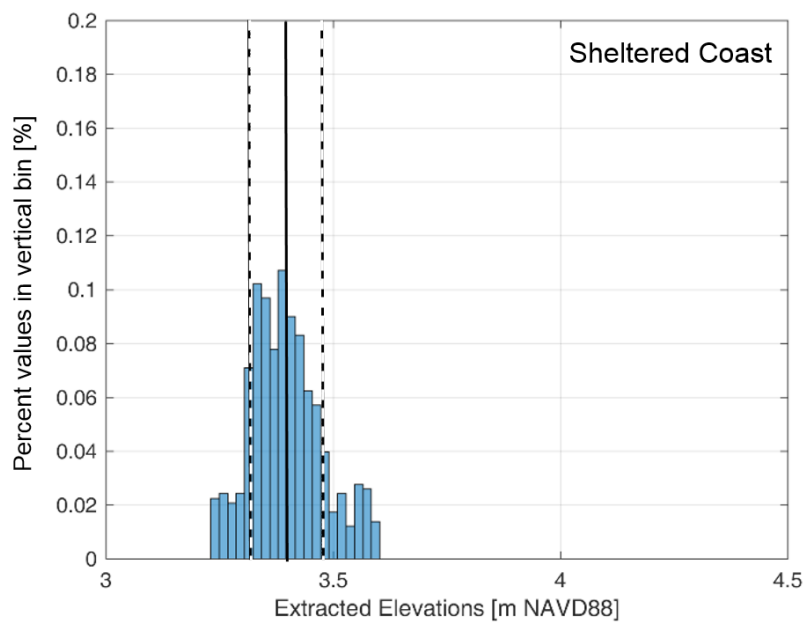

Figure 6. Extracted elevations of approximate water levels at Nome for sheltered coast (top) and exposed coast (bottom) locations. Open coast locations include a rock revetment (bottom left) and sandy beach (bottom right). Mean elevation is plotted as the solid black line +/- standard deviation at the dashed black and white lines.
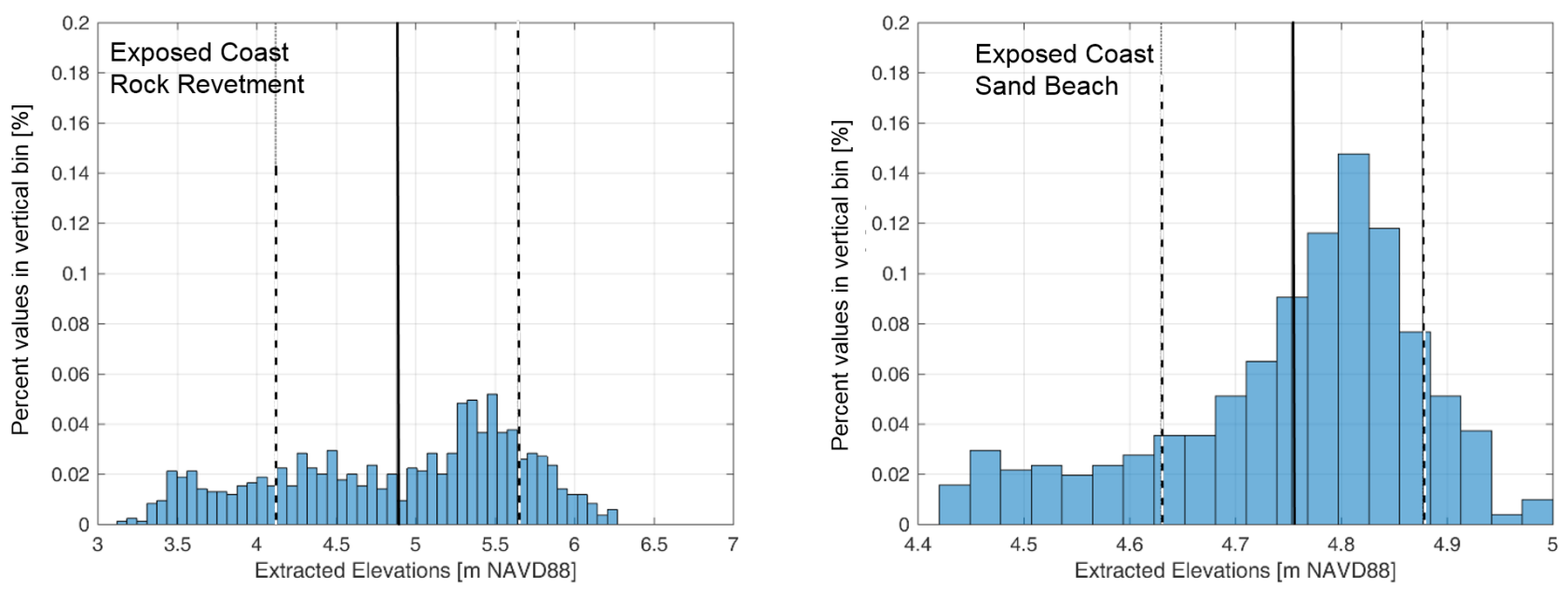
ground photos on orthoimagery co-registered with digital elevation models. The extracted elevation in the sheltered coastal environment compared well to the measured water level representing exposed coast still water level, although the photo-derived water level was still slightly greater $(0.8 \mathrm{ft}[0.24 \mathrm{~m}]$ difference). This difference may have been due to terrestrial inputs not included in exposed coast still water level values. Water levels extracted from exposed coast locations were greater than water levels from the sheltered coast, which is expected where waves run up the beach, resulting in marine total water level. To reduce uncertainty in photo-derived water levels, data collectors should take photos at (1) the intersection of aerial photo-identifiable features, (2) low-slope ground surfaces, (3) even ground surfaces, and (4) multiple exposed and sheltered coastal locations. By collecting photos on both sheltered and exposed coasts, multiple types of water level components may be measured, which is not possible with a single tide gauge or similar device.

Using photographs collected at peak inundation can provide water level elevations where there is no observational equipment, but where high resolution orthoimagery and co-registered digital elevation models are available. High resolution orthoimagery and digital elevation models are available for much of western Alaska, making it possible to collect storm water level information at communities without tide gauges and where the installation of new tide gauges is not likely.

\section{ACKNOWLEDGMENTS}

This research is funded by the Alaska Ocean Observing Systems. Photographs collected during and immediately following the storm event were taken by Gay Sheffield (Nome), and Jack Fagerstrom (Golovin). This work was made possible by local cooperation and the generous donation of residents' time. Thoughtful reviews by Ann Gibbs and Chris Maio greatly improved this report.

\section{REFERENCES CITED}

Alaska Ocean Observing System (AOOS), 2016, Coastal \& nearshore water level observations in Alaska, http://www. aoos.org/wp-content/uploads/2011/05/2016_Alaska_ Water_Level_Observations_v1-0.pdf

Blier, W., Keefe, S., Shaffer, W.A., and Kim, S.C., 1997, Storm surges in the region of western Alaska: Monthly Weather Review, v. 125, no. 12, p. 3094-3108.
DGGS Staff, 2017, Alaska Tidal Datum Portal: Alaska Division of Geological \& Geophysical Surveys [website]: found at http://dggs.alaska.gov/sections/engineering/ak-tidaldatum-portal/calculator.php

U.S. General Accounting Office (now U.S. Government Accountability Office) (GAO), 2003, Alaska Native villages: Most are affected by flooding and erosion, but few qualify for federal assistance: U.S. General Accounting Office Report GAO-04-142, 91 p.

U.S. Government Accountability Office (GAO), 2009, Alaska Native villages: Limited progress has been made on relocating villages threatened by flooding and erosion: U.S. Government Accountability Office Report GAO-09$551,53 \mathrm{p}$.

Moritz, Heidi, White, Kathleen, and Gouldby, Ben, 2016, An updated USACE approach to the evaluation of coastal total water levels for present and future flood risk analysis: $3^{\text {rd }}$ European Conference on Flood Risk Management, E3S Web of Conferences 7 (2016) 0102, 9 p. https://doi. org/10.1051/e3sconf/20160701012

National Oceanic and Atmospheric Administration (NOAA), 2016a, Meteorological Development Laboratory, National Weather Service [website], last accessed November 2016. http://www.nws.noaa.gov/mdl/etsurge/index.ph $\mathrm{p}$ ? page $=$ stn $\&$ region $=$ ak $\&$ datum $=$ msl $\&$ list $=\&$ map $=0$ 48\& type $=$ both\&stn $=$ akcarl

National Oceanic and Atmospheric Administration (NOAA), 2016b, Tides \& Currents, Center for Operational Oceanographic Products and Services (CO-OPS) [website], last accessed November 2016. https://tidesandcurrents. noaa.gov/stationhome.html?id=9468756

Overbeck, J.R., Hendricks, M.D., and Kinsman, N.E.M., 2016, Photogrammetric digital surface models and orthoimagery for 26 coastal communities of western Alaska: in DGGS Staff, Elevation Datasets of Alaska: Alaska Division of Geological \& Geophysical Surveys Raw Data File 2016-1, 3 p. http://doi.org/10.14509/29548

Overbeck, J.R., Kinsman, N.E.M., and Misra, Debasmita, 2015, Coastal vulnerability of a populated arctic spit: A case study of Golovin, Alaska, USA: Shore \& Beach, v. 83, no. 4 , p. $35-47$.

Stockdon H.F., Holman R.A., Howd P.A., Sallenger, A. H, 2006, Empirical parameterization of setup, swash, and runup: Coastal Engineering, v. 53, n. 7, p. 573-588. http:// dx.doi.org/10.1016/j.coastaleng.2005.12.005

U.S. Army Corps of Engineers (USACE), 2009, Alaska Baseline Erosion Assessment: Study Findings and Technical Report: U.S. Army Corps of Engineers Alaska District, 65 p.

Wise, J.L., Comiskey, A.L., and Becker, Jr., R., 1981, Storm surge climatology and forecasting in Alaska: Arctic Environmental Information and Data Center, 32 pp. 